\title{
ANALISIS STRUKTUR JEMBATAN BOX GIRDER DENGAN PENAMPANG KURVA PARABOLIK SINGLE CELL
}

\author{
Jason Ongkosurya ${ }^{1}$ dan FX. Supartono ${ }^{2}$ \\ ${ }^{1}$ Program Studi Sarjana Teknik Sipil, Universitas Tarumanagara, Jl. Letjen S. Parman No.1 Jakarta \\ Email: jason.ong097@gmail.com \\ ${ }^{2}$ Program Studi Sarjana Teknik Sipil, Universitas Tarumanagara, Jl. Letjen S. Parman No.1 Jakarta \\ Email: fxsupartono@gmail.com
}

\begin{abstract}
ABSTRAK
Box Girder adalah salah satu kompenen penting dari sekian banyak komponen struktur dari pembuatan jembatan segmental box girder yang berperan dalam menyalurakan gaya yang diterima dari lapisan perkerasan ke pier (kolom). Bentuk dari box girder sangat mempengaruhi ketahanan dan kekuatan dari suatu jembatan, serta effisiensi dari jembatan. Merubah bentuk dari box girder akan mempengaruhi inersia, beban sendiri, perletakan tendon. Yang menjadi komponen utama dalam perancangan jembatan post - tension box girder. Dengan bantuan program MIDAS CIVIL 2019 akan dianalisa gaya, berat sendiri. Lendutan dan jumlah tendon yang terjadi serta perubahannya akibat perubahan bentuk box girder.
\end{abstract}

Kata kunci : box girder, bentuk box girder, effisiensi, jumlah tendon.

\section{PENDAHULUAN}

Indonesia merupakan negara dengan urutan keempat dunia mengenai jumlah penduduk, dan merupakan negara kepulauan terbesar di dunia. Setiap tahun jumlah penduduk di Indonesia semakin bertambah disetai dengan meningkatnya kebutuhan masyarakat akan transportasi, sehingga membuat kota-kota di Indonesia menjadi kota macet. Untuk menangani hal tersebut, di bawah kepemimpinan Presiden Joko Widodo, pembangunan infrastruktur menjadi prioritas Bangsa Indonesia.

Salah satu prioritas pembangunan infrastruktur di Indonesia yaitu pembangunan jembatan. Pembangunan jembatan mempermudah dan mempercepat konektivitas antar wilayah mulai dari melewati keadaan geografis yang sulit maupun melewati titik-titik kemacetan. Salah satu infrastruktur jembatan yang sering ditemukan adalah jalan layang (fly over). Jalan layang dibangun untuk mengatasi permasalahan lalu lintas yang dikarenakan keterbatasan ruang datar perencanaan jembatan layang yang sering dipakai adalah metode jembatan box girder dengan prinsip beton prategang.

Seiring dengan makin berkembangnya teknologi maka konstruksi jembatan harus direncanakan sesuai dengan tuntutan transportasi baik dari segi kenyamanan, keamanan, maupun keindahan. Kemampuan dan ketahanan sebuah jembatan dipengaruhi oleh jenis dan bentuk penampang dari box girder. Keindahan dari jembatan layang box girder paling dapat terlihat dari bentuk penampang box girder-nya. Box girder merupakan satu balok struktural pada jembatan yang menerima beban dari slab yang kemudian diteruskan ke kolom (pier).

Dalam merencanakan suatu jembatan bentuk dari box girder merupakan hal yang perlu diperhatikan. Bentuk dari box girder mempengaruhi inersia penampang, beban,persebaran gaya dalam, dan keindahan. Box girder ini berperan menyalurkan gaya yang diterima dari pelat kemudian disalurkan ke kolom.

\section{Beton prategang}

Beton prategang terdiri dari beberapa material yaitu beton, baja prategang, grouting dan selongsong (duct). Pada material beton konvensional, Beton yang memikul beban akan mengalami tegangan pada sisi atas dan bawah penampang. Sisi atas penampang akan mengalami tegangan tekan dan sisi bawah penampang akan mengalami tegangan tarik. Berdasarkan sifatnya yang getas, sehingga membuat material beton tidak kuat dalam mengalami tarik. Sehingga menurut Nawy (2001) menyatakan bahwa pada balok prategang, balok diasumsikan bersifat 
homogen dan elastis. Ketidakmampuan beton untuk menahan tegangan tarik, digantikan oleh tegangan tekan yang diakibatkan oleh tendon prategang.

\section{Kehilangan prategang}

Kehilangan prategang adalah berkurangnya gaya yang bekerja pada tendon dalam tahap-tahap pembebanan baik akibat penarikan baja prategang maupun akibat pengruh waktu. Kehilangan prategang pada struktur beton prategang diilustrasikan pada gambar 1 di bawah ini.

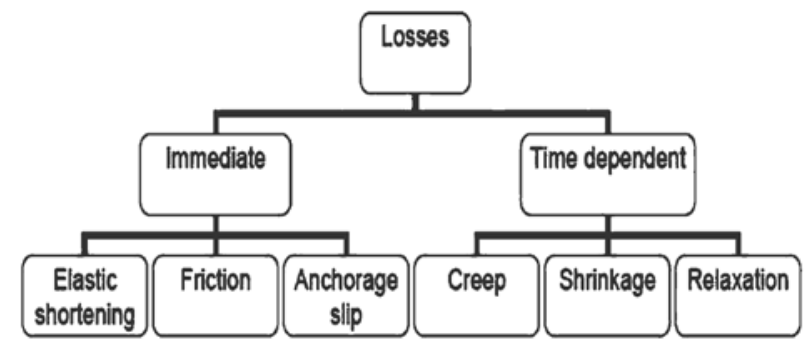

Gambar 1. Berbagai Kehilangan Gaya Prategang (Sumber: Edison Leo, 2018)

Berdasarkan SNI 2847:2013, sumber-sumber kehilangan prategang dalam menentukan tegangan efektif dalam baja prategang meliputi dudukan baja prategang saat penyaluran, perpendekan elastis beton, rangkak beton, susut beton, relaksasi tegangan baja prategang dan kehilangan friksi akibat kurvatur sengaja atau tidak sengaja pada tendon pasca-tarik.

Saat penarikan tendon pada struktur prategang pasca-tarik akan terjadi gesekan antara beton dan tendon prategang yang mengakibatkan berkurangnya gaya prategang yang terjadi. Gesekan ini dipengaruhi oleh kelengkungan tendon arah vertikal maupun horizontal dari gaya prategang seperti pada gambar 2 di bawah ini.

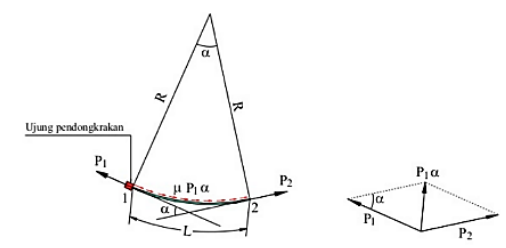

Gambar 2. Gaya Prategang Bekerja pada Tendon Lengkung (Sumber: Soetoyo , 2017)

Kehilangan gaya prategang akibat gesekan tendon dapat dihitung menggunakan rumus 1 sebagai berikut:

$$
F_{p F}=F_{0} \cdot e^{-(\mu \alpha+k x)}
$$

$F_{p F}=$ kehilangan gaya prategang akibat gesekan tendon $(\mathrm{N}), F_{0}=$ gaya prategang awal $(\mathrm{N}), \mu=$ koefisien gesek kelengkungan (rad), $\alpha=$ sudut kelengkungan tendon $\left({ }^{\circ}\right)$, dan $k=$ koefisien wobble (per meter).

Pada struktur pasca-tarik, saat penguncian tendon yang telah ditarik akan mengalami slip angkur dari mesin penarik dan ditahan baji pada angkur. Blok angkur yang mengalami pergerakan akan mengurangi gaya yang terjadi pada tendon baja. Hal ini menyebabkan perpendekan tendon yang mengakibatkan adanya kehilangan gaya prategang pada daerah dekat pengangkuran sepanjang $\mathrm{L}_{\text {set. }}$ seperti pada gambar 3 di bawah ini.

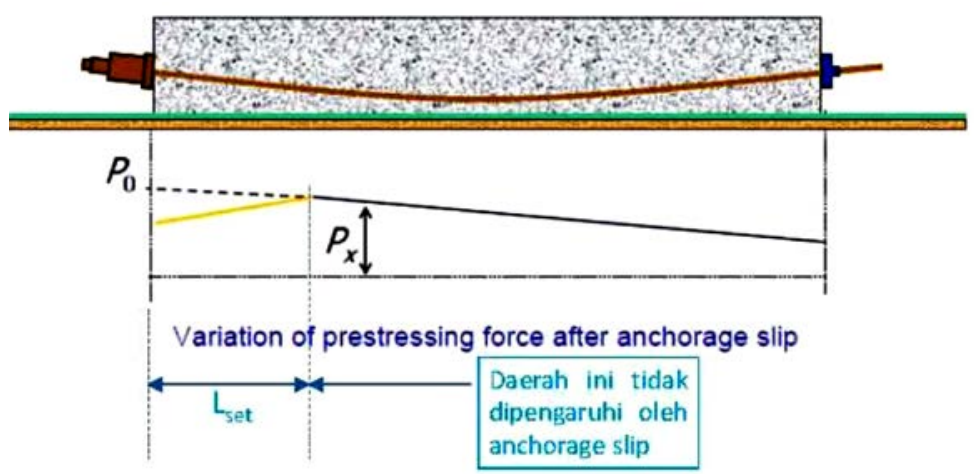

Gambar 3. Diagram Gaya Prategang di Sekitar Angkur Hidup (Sumber: Edison Leo, 2018) 
Besarnya slip angkur tergantung pada jenis atau sistem pengangkuran yang digunakan. Data besarnya slip angkur yang digunakan pada tugas akhir diperoleh dari spesifikasi angkur VSL yaitu sebesar $7 \mathrm{~mm}$. Penentuan kehilangan prategang akibat slip angkur dihitung dengan menggunakan rumus 2 sampai 4 sebagai berikut:

$$
\begin{aligned}
\mathrm{F}_{0 \eta} & =\frac{\Delta F}{L} \\
\mathrm{~L}_{\text {set }} & =\sqrt{\frac{\Delta \mathrm{s} \times A_{p} \times E_{p}}{\mathrm{~F}_{0 \eta}}} \\
\Delta F_{p A} & =2 \times \mathrm{F}_{0 \eta} \times \mathrm{L}_{\text {set }}
\end{aligned}
$$

dengan $\mathrm{F}_{0 \eta}=$ kehilangan gaya prategang akibat friksi per satuan Panjang $(\mathrm{N} / \mathrm{mm}), \Delta F_{p A}=$ kehilangan gaya prategang akibat friksi $(\mathrm{N}), \mathrm{L}=$ panjang bentang $(\mathrm{mm})$, dan $\mathrm{L}_{\mathrm{set}}=$ panjang bentang yang dipengaruhi oleh slip angkur (mm).

Jika struktur prategang terdiri lebih dari 1 tendon, maka menurut hokum Hooke beton akan mengalami perpendekan elastis setiap step penarikan tendon yang akan mengakibatkan memendeknya beton dan baja prategang.ilustrasi terlihat pada gambar 4 di bawah ini:

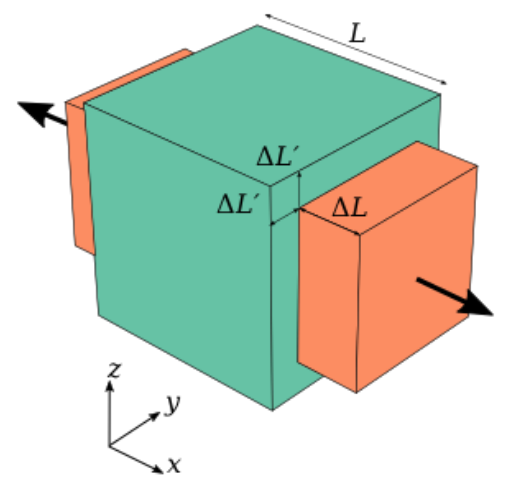

Gambar 4. Penggambaran Elastik hukum Hooke (Sumber : www.wikipedia.com, 2019)

Dikarenakan penpendekan elastis bahan tersebut maka akan menyebabkan berkurangnya gaya prategang. Semakin banyak jumlah tahapan penarikan maka, kehilangan prategang akibat perpendekan elastic semakin besar. Penentuan kehilangan prategang akibat perpendekan elastis dihitung dengan menggunakan rumus 5 sebagai berikut:

$$
\Delta F_{p E S}=m \times E S \times A_{p}
$$

dengan $\Delta F_{p E S}=$ kehilangan gaya prategang akibat perpendekan elastis $(\mathrm{N}), \mathrm{m}=$ perbandingan nilai modulus elastisitas baja prategang dengan modulus elastisitas beton, dan $A_{p}=$ luas tendon $\left(\mathrm{mm}^{2}\right)$.

Rangkak pada beton terjadi karena peningkatan deformasi terhadap waktu pada kondisi beban yang konstan. Rangkak akan mengakibatkan penambahan regangan pada penampang. Nilai rangkak pada beton dipengaruhi oleh nilai mutu beton, pada beton mutu rendah nilai rangkak akan lebih besar dibandingkan dengan beton mutu tinggi Besarnya kehilangan prategang akibat rangkak pada beton dapat dihitung menggunakan rumus 6 di bawah ini:

$$
\Delta F_{p C R}=m \times K_{c r} \times\left(f_{c s}-f_{c d s}\right)
$$

dengan $\Delta F_{p C R}=$ kehilangan gaya prategang akibat rangkak beton $(\mathrm{N}), \mathrm{K}_{\mathrm{cr}} \quad=1.60$ untuk komponen struktur pasca-tarik dan 2.00 untuk komponen struktur pra-tarik. , $\mathrm{f}_{\mathrm{cs}}=$ tegangan beton pada titik berat tendon akibat berat sendiri box $(\mathrm{MPa})$, dan $\mathrm{f}_{\mathrm{cds}}=$ tegangan beton pada titik berat tendon akibat beban mati tambahan $(\mathrm{MPa})$.

Susut merupakan perubahan volume pada beton tidak dipengaruhi oleh faktor beban. Faktor yang mengakibatkan susut beton meliputi sifat bahan dasar beton,rasio air semen, suhu pada saat pengeringan, kelembeban udara, umur beton saat beban berkerja.. Material yang mengalami penyusutan akan menimbulkan regangan susut. Ada beberapa ketentuan untuk memperhitungkan kehilangan gaya prategang akibat susut, berikut ini adalah salah satu cara yang dapat digunakan sepert pada rumus 7 dan 8 di bawah ini:

$$
\begin{array}{ll}
\varepsilon_{\mathrm{sh}} & =\frac{0.0002}{\log (t+2)} \\
\Delta \mathrm{f}_{\mathrm{pSH}} & =E_{p} \times \varepsilon_{s h}
\end{array}
$$


dengan $\varepsilon_{\mathrm{sh}}=$ regangan susut dalam beton, $\mathrm{t}=$ umur pembebanan (hari),$\Delta \mathrm{f}_{p S H}=$ kehilangan gaya prategang akibat susut $(\mathrm{N})$, dan $\mathrm{E}_{\mathrm{p}}=$ modulus elastisitas tendon $(\mathrm{MPa})$.

Kehilangan gaya prategang akibat relaksasi baja terjadi karena adanya perpanjangan konstan dari baja prategang terhadap waktu. Besarnya penurunan gaya prategang tersebut tidak hanya bergantung pada durasi gaya prategang tersebut, tetapi juga dipengaruhi oleh rasio antara tegangan awal baja prategang dan kuat leleh baja prategang $\left(\frac{f_{p i}}{f_{p y}}\right)$.

Berdasarkan SNI 2847:2013 membatasi tegangan tarik untuk tendon pasca-tarik, pada daerah angkur dan sambungan sesaat setelah transfer gaya (Servis) sebesar $0.60 \mathrm{f}_{\mathrm{pu}}$ dan nilai $\mathrm{f}_{\mathrm{py}}$ dapat dihitung dari:

- $\quad$ Batang prategang, $\mathrm{f}_{\mathrm{py}}=0.80 \mathrm{f}_{\mathrm{pu}}$

- $\quad$ Tendon stress relieved, $\mathrm{f}_{\mathrm{py}}=0.85 \mathrm{f}_{\mathrm{pu}}$

- $\quad$ Tendon relaksasi rendah, $\mathrm{f}_{\mathrm{py}}=0.90 \mathrm{f}_{\mathrm{pu}}$

Kehilangan gaya prategang akibat relaksasi dapat dihitung dengan menggunakan rumus 9 sebagai berikut:

$$
\Delta f_{p R}=f_{p i}^{\prime} \times\left(\frac{\log t}{10}\right) \times\left(\frac{f_{p i}^{\prime}}{f_{p y}}-0.55\right)
$$

dengan $\Delta f_{p R}=$ kehilangan gaya prategang akibat relaksasi baja, $f^{\prime}{ }_{p i}=$ tegangan tarik tendon sesaat setelah transfer gaya , dan $f_{p y}=$ kuat leleh baja prategang.

\section{METODOLOGI PENELITIAN}

\section{Konsep perencanaan jembatan}

Perencanaan jembatan precast segmental box girder single cell ini sepanjang $300 \mathrm{~m}$ yang dibagi menjadi 5 bentang sama panjang. Dengan data perencanaan jembatan sebagai berikut:

- Panjang 1 bentang $\quad$ : $60 \mathrm{~m}$

- Panjang 1 segmen : $3 \mathrm{~m}$

- Bentang bersih jembatan : $57 \mathrm{~m}$

- Lebar total jembatan : : $10 \mathrm{~m}$

- Lebar lantai kendaraan : $7 \mathrm{~m}$

- Jumlah lajur : : 2 lajur, 2 arah

Box girder ini direncanakan memiliki lebar 10 m dan tinggi 3.2 m dengan f' ${ }_{\mathrm{c}}$ sebesar $50 \mathrm{MPa}$. Tendon direncanakan menggunakan strand jenis Uncoated Seven Wire Super Strands ASTM A-416-06 Grade 270 dan menggunakan angkur dari VSL yaitu Anchorage Type GC-Spiral Reinforcement dengan fy= $460 \mathrm{~N} / \mathrm{mm}^{2}$.

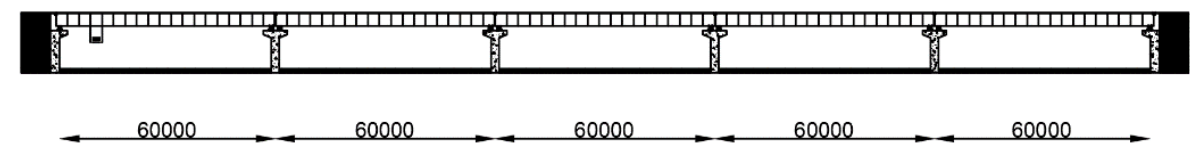

Gambar 5. Tampak Keseluruhan Memanjang Jembatan
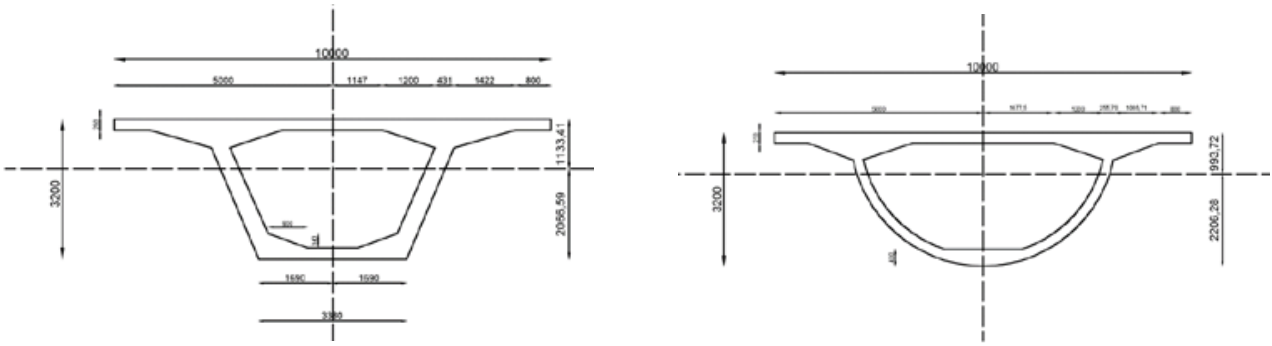

Gambar 6. Desain Penampang Jembatan 


\section{Kerangka kerja}

Gambar dibawah ini merupakan alur pekerjaan yang dilakukan dalam melakukan analisis perhitungan.

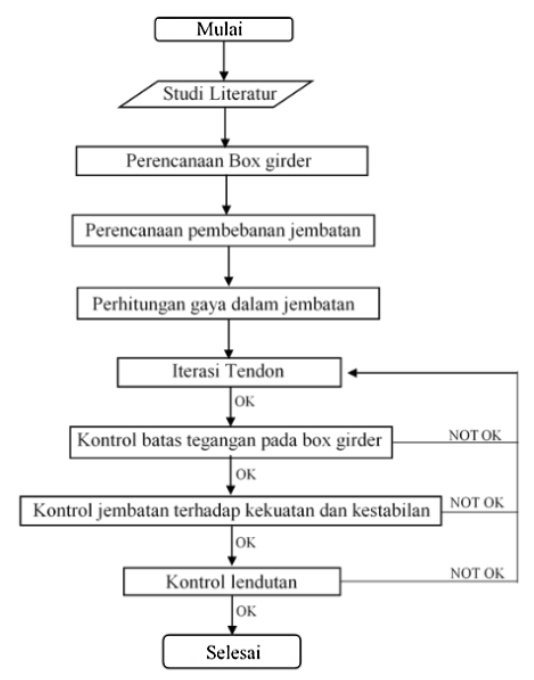

Gambar 7. Diagram Alir

\section{HASIL ANALISIS}

\section{Tegangan ijin bahan}

Beton memiliki tegangan ijin yang berbeda pada kondisi transfer dan kondisi servis sesuai dengan peraturan yang diijinkan.

- Pada kondisi transfer
o $\bar{\sigma}_{\text {tekan }}\left(\mathrm{f}_{\mathrm{ct}}\right)$
$=24 \mathrm{MPa}$
o $\bar{\sigma}_{\text {tarik }}\left(f_{t t}\right)$
$=0 \mathrm{MPa}$

- Pada kondisi servis
o $\bar{\sigma}_{\text {tekan }}\left(\mathrm{f}_{\mathrm{cs}}\right)$
$=22.5 \mathrm{MPa}$
o $\bar{\sigma}_{\text {tarik }}\left(f_{t t}\right)$
$=0 \mathrm{MPa}$

- Modulus elastisitas beton

$\mathrm{E}=33234.0187 \mathrm{MPa}$

Tendon prategang juga memiliki tegangan tarik yang diijinkan sesuai dengan peraturan yang berlaku.

- Tegangan tarik ijin kabel (jacking) $\quad=1784.4 \mathrm{MPa}$

- Tegangan tarik ijin kabel (setelah pengangkuran) $=1488.0 \mathrm{MPa}$

\section{Analisa penampang box girder}

Berdasarkan hasil pre-eliminary design, berikut hasil properti dari kedua penampang box girder pada tabel dibawah ini:

Tabel 1. Analisa Penampang Box Girder

\begin{tabular}{|c|c|c|c|c|c|c|c|}
\hline \multirow{2}{*}{$\begin{array}{c}\text { Jenis } \\
\text { Penampang }\end{array}$} & \multirow{2}{*}{$\begin{array}{c}\text { Luas Penampang } \\
\left(\mathrm{mm}^{2}\right)\end{array}$} & \multicolumn{2}{|c|}{ Titik berat } & \multirow{2}{*}{ Inersia $\left(\mathrm{mm}^{4}\right)$} & \multirow{2}{*}{$\begin{array}{c}\text { Radius } \\
\text { Girasi }\left(r^{2}\right)\end{array}$} & \multicolumn{2}{|c|}{ Kern } \\
\hline & & $y^{t}(\mathbf{m m})$ & $y_{b}(\mathbf{m m})$ & & & $\mathbf{k}^{\mathrm{t}}(\mathbf{m m})$ & $\mathbf{k}^{\mathbf{b}}(\mathbf{m m})$ \\
\hline Trapezoid & 7094656 & 1133.4138 & 2066.5862 & $9.2305 \times 10^{12}$ & 1301049.691 & 629.5647 & 1147.9035 \\
\hline Parabolic & 5858924 & 993.7244 & 2206.2756 & $7.0904 \times 10^{12}$ & 1210188.082 & 548.5208 & 1217.8307 \\
\hline
\end{tabular}




\section{Pembebanan}
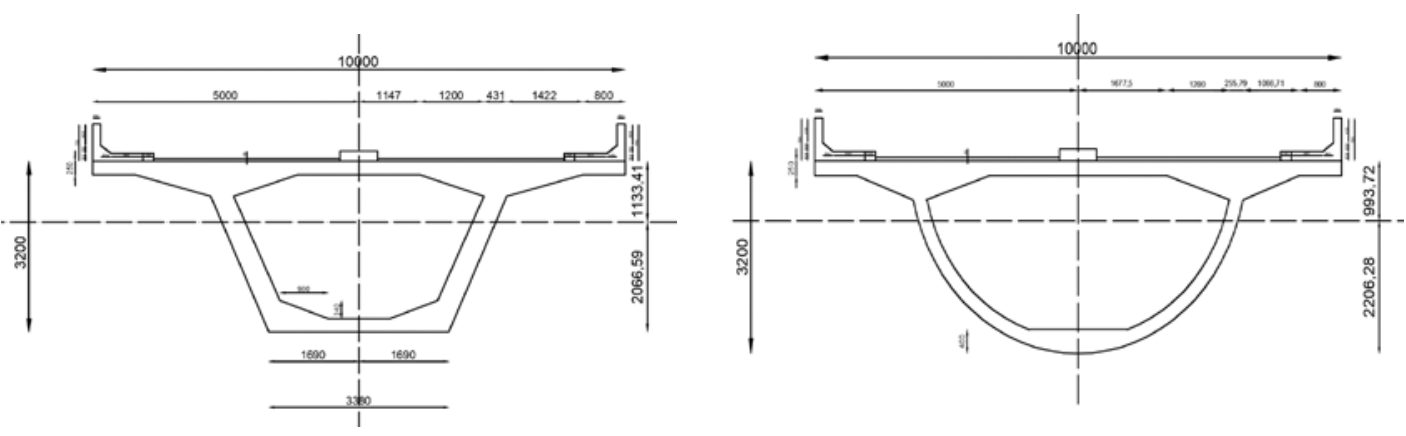

Gambar 8. Penampang Box girder dengan penampang sekunder

Tabel 2. Pembebanan pada Box Girder

\begin{tabular}{cccc}
\hline Berat Sendiri & Trapezoid & 177.365 & $\mathrm{kN} / \mathrm{m}$ \\
\cline { 2 - 4 }$(\mathrm{DL})$ & Parabolic & 146.473 & $\mathrm{kN} / \mathrm{m}$ \\
\hline \multirow{2}{*}{$\begin{array}{c}\text { Beban Mati } \\
\text { Tambahan (SDL) }\end{array}$} & Berat Aspal & 7.7 & $\mathrm{kN} / \mathrm{m}$ \\
\cline { 2 - 4 } & Berat trotoar+kerb+railing & 11.88 & $\mathrm{kN} / \mathrm{m}$ \\
\hline Beban Hidup & Berat median & 3.08 & $\mathrm{kN} / \mathrm{m}$ \\
\cline { 2 - 4 }$($ LL) & Beban terbagi rata (UDL) & 48.0788 & $\mathrm{kN} / \mathrm{m}$ \\
\hline
\end{tabular}

\section{Kebutuhan tendon}

Menggunakan Brosur VSL (Sever Wire Super Strands Grade 270), dengan spesifikasi sebagai berikut :

- $\quad$ Diameter nominatstands

- $\quad$ Luas penampang nominal satu strands

$: \mathrm{d} \quad=15.24 \mathrm{~mm}$

- $\quad$ Tegangan leleh strand

- $\quad$ Tegangan putus strand

$: \mathrm{A}_{\mathrm{p}} \quad=140 \mathrm{~mm}^{2}$

- $\quad$ Beban putus

- $\quad$ Modulus elastisitas

$: \mathrm{f}_{\mathrm{py}} \quad=1676 \mathrm{MPa}$

$: \mathrm{f}_{\mathrm{pu}} \quad=1860 \mathrm{MPa}$

$: \mathrm{F}_{\mathrm{pk}} \quad=260.7 \mathrm{kN}$

$: \mathrm{Es} \quad=195000 \mathrm{MPa}$

Perhitungan jumlah tendon menggunakan metode C line dan pada saat jembatan dalam kondisi servis. Pada table 3 di bawah ini.

Tabel 3. Perhitungan Jumlah Tendon

\begin{tabular}{ccc}
\hline $\mathrm{M}_{\text {maks }}$ & Trapezoid & Circular \\
\cline { 2 - 3 }$(\mathrm{kN} . \mathrm{m})$ & 104283.0 & 91971.6 \\
\hline $\mathrm{e}_{\mathrm{c}}(\mathrm{mm})$ & 629.5643 & 548.1327 \\
\hline $\mathrm{e}$ tendon $(\mathrm{mm})$ & 1835.1576 & 1929.1327 \\
\hline $\mathrm{Z}(\mathrm{mm})$ & 2464.7219 & 2477.6480 \\
\hline $\mathrm{F}_{\mathrm{s}}(\mathrm{kN})$ & 42310.2501 & 31720.5272 \\
\hline $\mathrm{n}$ strand & 270.8029 & 237.5272 \\
\hline $\mathrm{n}$ tendon & 14 & 14 \\
\hline
\end{tabular}

\section{Letak tendon}

Berdasarkan hasil iterasi dan pengecekan terhadap tegangan dan kestabilan jembatan didapat posisi tendon untuk kedua bentuk Box Girder yang akan dibandingkan sebagai berikut : 


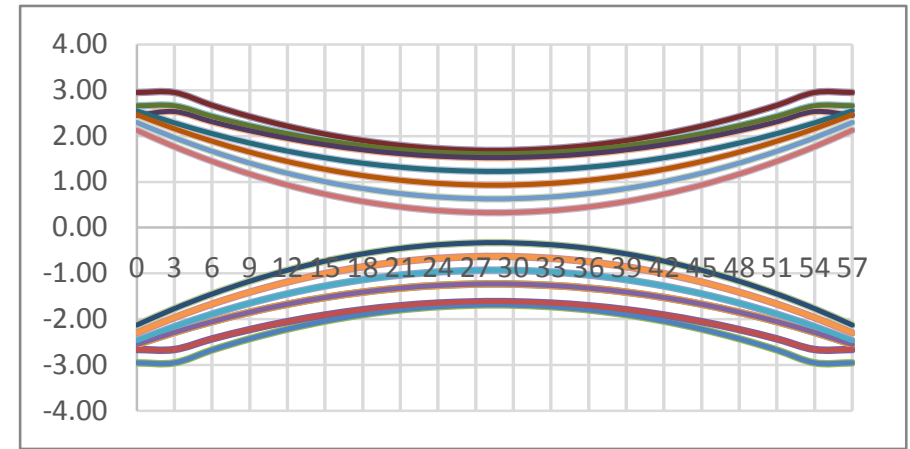

Gambar 9. Tendon Tampak Atas Jembatan (Trapezoid)

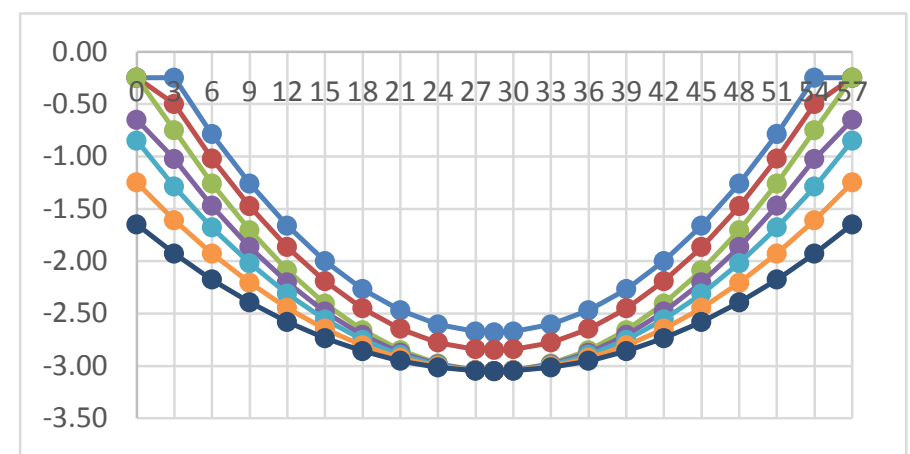

Gambar 10. Tendon Tampak Samping Jembatan (Trapezoid)

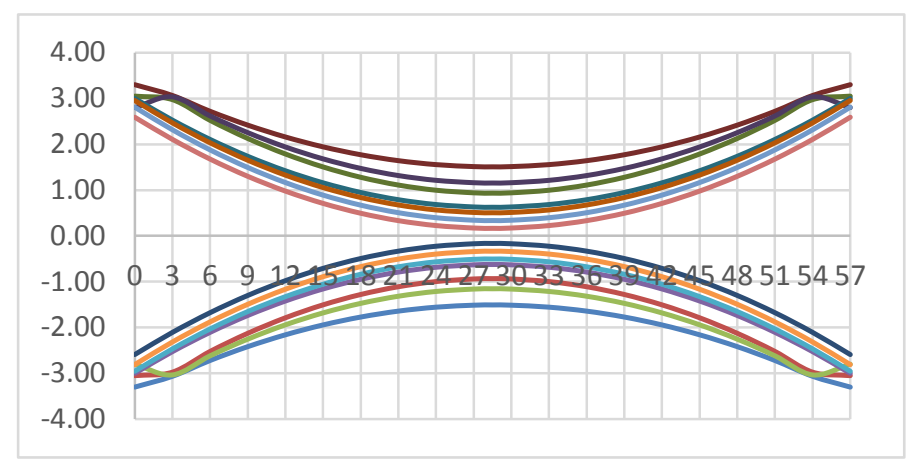

Gambar 11. Tendon Tampak Atas Jembatan (Parabolic)

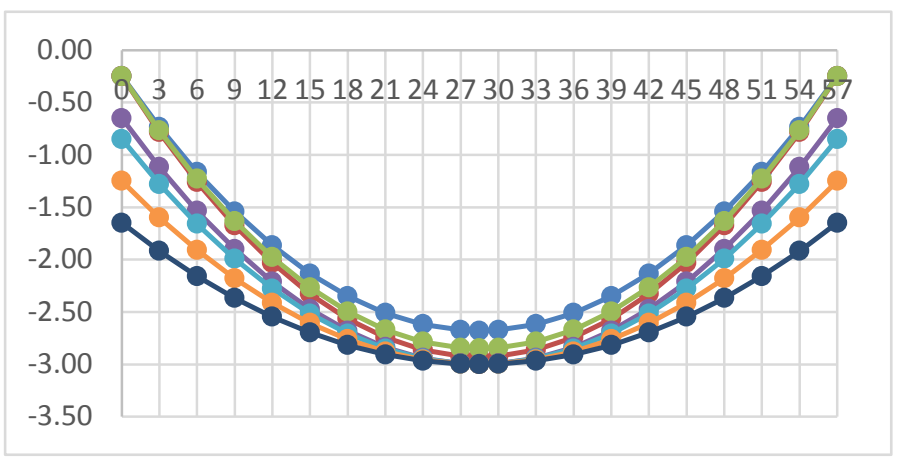

Gambar 12. Tendon Tampak Atas Jembatan (Parabolic) 


\section{Kehilangan gaya prategang}

Kehilangan gaya prategang dianalisa, dengan kehilangan gaya jangka pendek (gesekan, slip angkur dan perpendekan elastis) maupun kehilangan gaya jangka Panjang (rangkak beton, susut beton, dan relaksasi baja). Besar kehilangan gaya prategang disajikan dalam bentuk tabel di bawah ini.

Tabel 4. Kehilangan Gaya Prategang Sepanjang Bentang Trapezoid (\%)

\begin{tabular}{ccccccc}
\hline $\begin{array}{c}\text { Jarak } \\
(\mathbf{m})\end{array}$ & Gesekan & $\begin{array}{c}\text { Slip } \\
\text { Angkur }\end{array}$ & $\begin{array}{c}\text { Perpendekan } \\
\text { Elastis }\end{array}$ & Rangkak & Susut & $\begin{array}{c}\text { Relaksasi } \\
\text { Baja }\end{array}$ \\
\hline 0 & 77.78 & 71.43 & 71.00 & 70.98 & 69.56 & 66.89 \\
\hline 3 & 75.62 & 70.54 & 70.02 & 70.00 & 68.58 & 65.91 \\
\hline 6 & 75.15 & 71.34 & 70.70 & 70.67 & 69.25 & 66.58 \\
\hline 9 & 74.68 & 72.14 & 71.35 & 71.31 & 69.89 & 67.23 \\
\hline 12 & 74.22 & 72.94 & 72.01 & 71.96 & 70.54 & 67.88 \\
\hline 15 & 73.76 & 73.76 & 72.69 & 72.63 & 71.21 & 68.55 \\
\hline 18 & 73.31 & 73.31 & 72.10 & 72.04 & 70.62 & 67.95 \\
\hline 21 & 72.86 & 72.86 & 71.51 & 71.44 & 70.02 & 67.36 \\
\hline 24 & 72.42 & 72.42 & 70.96 & 70.88 & 69.46 & 66.79 \\
\hline 27 & 71.98 & 71.98 & 70.43 & 70.34 & 68.92 & 66.26 \\
\hline 28.5 & 71.76 & 71.76 & 70.07 & 69.98 & 68.56 & 65.90 \\
\hline 30 & 71.98 & 71.98 & 70.43 & 70.34 & 68.92 & 66.26 \\
\hline 33 & 72.42 & 72.42 & 70.96 & 70.88 & 69.46 & 66.79 \\
\hline 36 & 72.86 & 72.86 & 71.51 & 71.44 & 70.02 & 67.36 \\
\hline 39 & 73.31 & 73.31 & 72.10 & 72.04 & 70.62 & 67.95 \\
\hline 42 & 73.76 & 73.76 & 72.69 & 72.63 & 71.21 & 68.55 \\
\hline 45 & 74.22 & 72.94 & 72.01 & 71.96 & 70.54 & 67.88 \\
\hline 48 & 74.68 & 72.14 & 71.35 & 71.31 & 69.89 & 67.23 \\
\hline 51 & 75.15 & 71.34 & 70.70 & 70.67 & 69.25 & 66.58 \\
\hline 54 & 75.62 & 70.54 & 70.02 & 70.00 & 68.58 & 65.91 \\
\hline 57 & 77.78 & 71.43 & 71.00 & 70.98 & 69.56 & 66.89 \\
\hline & & & & & &
\end{tabular}

Tabel 5. Kehilangan Gaya Prategang Sepanjang Bentang Parabolic (\%)

\begin{tabular}{ccccccc}
\hline $\begin{array}{c}\text { Jarak } \\
(\mathbf{m})\end{array}$ & Gesekan & $\begin{array}{c}\text { Slip } \\
\text { Angkur }\end{array}$ & $\begin{array}{c}\text { Perpendekan } \\
\text { Elastis }\end{array}$ & Rangkak & Susut & $\begin{array}{c}\text { Relaksasi } \\
\text { Baja }\end{array}$ \\
\hline 0 & 77.83 & 71.48 & 71.05 & 71.05 & 69.63 & 67.17 \\
\hline 3 & 75.71 & 70.63 & 70.11 & 70.04 & 68.62 & 66.16 \\
\hline 6 & 75.24 & 71.43 & 70.79 & 70.42 & 69.00 & 66.54 \\
\hline 9 & 74.77 & 72.23 & 71.44 & 72.13 & 70.71 & 68.24 \\
\hline 12 & 74.31 & 73.03 & 72.10 & 73.55 & 72.13 & 69.66 \\
\hline 15 & 73.85 & 73.85 & 72.78 & 75.15 & 73.73 & 71.27 \\
\hline 18 & 73.40 & 73.40 & 72.18 & 75.57 & 74.15 & 71.69 \\
\hline 21 & 72.95 & 72.95 & 71.60 & 76.03 & 74.61 & 72.15 \\
\hline 24 & 72.50 & 72.50 & 71.04 & 76.35 & 74.93 & 72.47 \\
\hline 27 & 72.06 & 72.06 & 70.51 & 76.49 & 75.07 & 72.61 \\
\hline 28.5 & 71.84 & 71.84 & 70.16 & 76.91 & 75.49 & 73.02 \\
\hline 30 & 72.06 & 72.06 & 70.51 & 76.49 & 75.07 & 72.61 \\
\hline 33 & 72.50 & 72.50 & 71.04 & 76.35 & 74.93 & 72.47 \\
\hline 36 & 72.95 & 72.95 & 71.60 & 76.03 & 74.61 & 72.15 \\
\hline 39 & 73.40 & 73.40 & 72.18 & 75.57 & 74.15 & 71.69 \\
\hline 42 & 73.85 & 73.85 & 72.78 & 75.15 & 73.73 & 71.27 \\
\hline 45 & 74.31 & 73.03 & 72.10 & 73.55 & 72.13 & 69.66 \\
\hline 48 & 74.77 & 72.23 & 71.44 & 72.13 & 70.71 & 68.24 \\
\hline 51 & 75.24 & 71.43 & 70.79 & 70.42 & 69.00 & 66.54 \\
\hline 54 & 75.71 & 70.63 & 70.11 & 70.04 & 68.62 & 66.16 \\
\hline 57 & 77.83 & 71.48 & 71.05 & 71.05 & 69.63 & 67.17 \\
\hline & & & & & & \\
\hline
\end{tabular}




\section{Perhitungan Post-tensioned Bar.}

Berdasrkan Hasil Perhitungan, dikarenakan lintasan tendon yang cukup ekstrim dikarenakan bentuk penampang parabolic box girder, maka ditambahkan post-tensioned bar sebagai penahan gaya lateral Tarik yang ditimbulkan oleh beton.

Menggunakan Brosur Dextra (Fully-threaded )

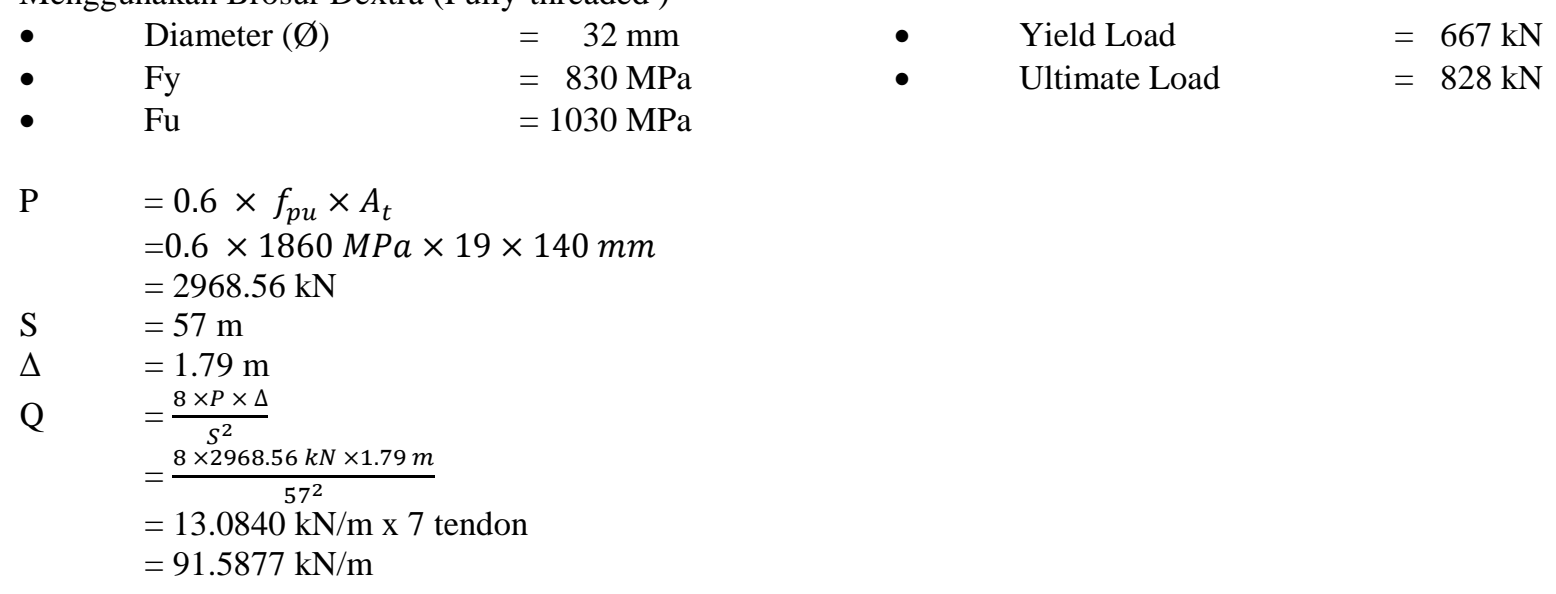

Untuk menahan gaya Q $=91.5877 \mathrm{kN} / \mathrm{m}$

ØLn $=0.5 \times$ ultimate Load

$=414 \mathrm{kN}$

$\mathrm{N} \quad=\frac{Q}{\emptyset L n}$ $=\frac{91.5877 \frac{\mathrm{kN}}{\mathrm{m}}}{414 \mathrm{kN}}=0.2212 /$ meter $\sim 1$ buah per 4.52 meter

Dipasang $\rightarrow$ Post tensioned bar dengan Ømm dengan jarak $3 \mathrm{~m}$. gaya penarikan post tensioned bar adalah $\frac{3}{4.52} \times$ $414 k N=274.8 \sim 280 k N$

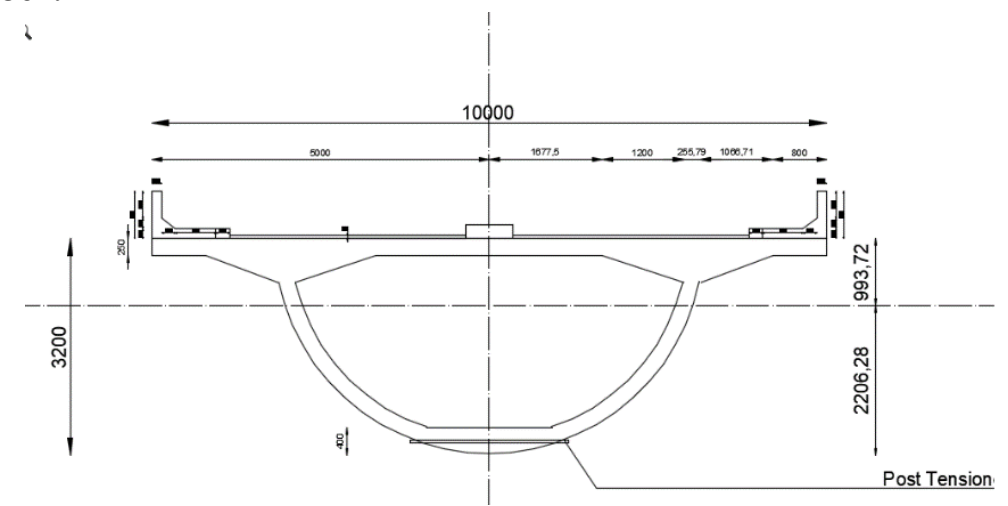

Gambar 13. Penampang parabolic box girder dengan post-tensioned bar.

\section{Lendutan Jembatan}

Berdasarkan hasil perhitungan, berikut lendutan yang terjadi dengan pembebananan Service load $(1.0 \mathrm{SW}+1.0$ SIDL + 1.0 LL) pada tabel dibawah ini.

Tabel 6. Tabel Lendutan yang terjadi

\begin{tabular}{ccccc} 
& \multicolumn{2}{c}{ Trapezoid Box Girder } & \multicolumn{2}{c}{ Parabolic Box Girder } \\
\hline $\mathrm{L}$ & dy $[\mathrm{mm}]$ & rz [radians] & dy $[\mathrm{mm}]$ & rz [radians] \\
\hline 0 & 0 & $-6.38 \mathrm{E}-03$ & 0 & $-7.32 \mathrm{E}-03$ \\
\hline 3 & -19.0475 & $-6.28 \mathrm{E}-03$ & -21.835 & $-7.20 \mathrm{E}-03$ \\
\hline 6 & -37.5037 & $-5.99 \mathrm{E}-03$ & -42.9931 & $-6.87 \mathrm{E}-03$ \\
\hline 9 & -54.8366 & $-5.54 \mathrm{E}-03$ & -62.8651 & $-6.35 \mathrm{E}-03$ \\
\hline
\end{tabular}


Tabel 6. Tabel Lendutan yang terjadi (Lanjutan)

Trapezoid Box Girder

\begin{tabular}{ccccc}
\hline $\mathrm{L}$ & dy $[\mathrm{mm}]$ & rz [radians] & dy $[\mathrm{mm}]$ & rz [radians] \\
\hline 12 & -70.5786 & $-4.94 \mathrm{E}-03$ & -80.9152 & $-5.66 \mathrm{E}-03$ \\
\hline 15 & -84.3269 & $-4.21 \mathrm{E}-03$ & -96.6816 & $-4.83 \mathrm{E}-03$ \\
\hline 18 & -95.7434 & $-3.38 \mathrm{E}-03$ & -109.776 & $-3.88 \mathrm{E}-03$ \\
\hline 21 & -104.554 & $-2.48 \mathrm{E}-03$ & -119.884 & $-2.84 \mathrm{E}-03$ \\
\hline 24 & -110.551 & $-1.51 \mathrm{E}-03$ & -126.765 & $-1.74 \mathrm{E}-03$ \\
\hline 27 & -113.589 & $-5.09 \mathrm{E}-04$ & -130.252 & $-5.84 \mathrm{E}-04$ \\
\hline 28.5 & -113.971 & $2.56 \mathrm{E}-16$ & -130.691 & $-9.19 \mathrm{E}-17$ \\
\hline 30 & -113.589 & $5.09 \mathrm{E}-04$ & -130.252 & $5.84 \mathrm{E}-04$ \\
\hline 33 & -110.551 & $1.51 \mathrm{E}-03$ & -126.765 & $1.74 \mathrm{E}-03$ \\
\hline 36 & -104.554 & $2.48 \mathrm{E}-03$ & -119.884 & $2.84 \mathrm{E}-03$ \\
\hline 39 & -95.7434 & $3.38 \mathrm{E}-03$ & -109.776 & $3.88 \mathrm{E}-03$ \\
\hline 42 & -84.3269 & $4.21 \mathrm{E}-03$ & -96.6816 & $4.83 \mathrm{E}-03$ \\
\hline 45 & -70.5786 & $4.94 \mathrm{E}-03$ & -80.9152 & $5.66 \mathrm{E}-03$ \\
\hline 48 & -54.8366 & $5.54 \mathrm{E}-03$ & -62.8651 & $6.35 \mathrm{E}-03$ \\
\hline 51 & -37.5037 & $5.99 \mathrm{E}-03$ & -42.9931 & $6.87 \mathrm{E}-03$ \\
\hline 54 & -19.0475 & $6.28 \mathrm{E}-03$ & -21.835 & $7.20 \mathrm{E}-03$ \\
\hline 57 & 0 & $6.38 \mathrm{E}-03$ & 0 & $7.32 \mathrm{E}-03$ \\
\hline
\end{tabular}

\section{KESIMPULAN}

Berdasarkan hasil analisis, maka dapat disimpulkan:

1. Beban mati sendiri / Self Weight Dari trapezoid gox girder $177.1 \mathrm{kN} / \mathrm{m}$ ' sedangkan parabolic box girder 146.5 $\mathrm{kN} / \mathrm{m}$ '. hasil tersebut menunjukan penurunan berat girder sebesar $17.25 \%$

2. Jumlah Strand Minimum yang dibutuhkan oleh setiap penampang berkurang yaitu 270.8 strand untuk trapezoid box girder dan 237.6 strand untuk circular box girder berarti pengurangan strand sebesar $12.26 \%$

3. Momen inersia dari 2 penampang adalah $9.2305 \times 10^{12} \mathrm{~mm}^{4}$ dengan lendutan $113.971 \mathrm{~mm}$ untuk trapezoid box girder dan $7.0903 \times 10^{12} \mathrm{~mm}^{4}$ dengan lendutan 130.691 untuk parabolic box girder. Sehingga dapat diambil kesimpulan bahwa circular box girder akan memiliki kekakuan yang lebih kecil dibandingkan dengan trapezoid box girder. Sehingga lendutan yang terjadi pada saat service load di tengah bentang memiliki perbedaan $14.67 \%$.

4. Dari hasil perhitungan untuk mendapat gaya prategang $60 \% \mathrm{f}_{\mathrm{pu}}$ pada tengah bentang, maka gaya tarik prategang pada ujung adalah 77 \% fpu untuk Bentuk Box girder.

\section{DAFTAR PUSTAKA}

AASHTO 2014 LRFD Bridge Design Specifications

Chandra, C., (2019). "Kekuatan Geser Single Shear Key dan Multiple Shear Key pada Jembatan Segmental Single Cell Box Girder Bentang Panjang”. Skripsi, Fakultas Teknik Universitas Tarumanagara, Jakarta.

Edison, L., (2018). Bahan Kuliah Konstruksi Konstruksi Beton Lanjutan Struktur Beton Prategang, Fakultas Teknik Universitas Tarumanagara, Jakarta.

Koseki, K., dan Breen, J. E. Exploratory Study of Shear Strength of Joint for Precast Segmental Bridges, Research Rep. No. 248-1. Texas: The Universitas Texas

Lin, T.Y. (2000). Desain Struktur Beton Prategang. Jakarta: Binarupa Aksara.

Podolny and Muller. (1982). Construction and Design of Prestressed Concrete Segmental Bridges. John Wiley\&Son, Canada

Prasetya, Wiratma A., Elvira, dan Gatot Setya Budi. (2016). "Perhitungan Jembatan Layang dengan Tipe Box Girder Beton Prategang untuk Pertemuan Jalan Mayor Alianyang dan Jalan Soekarno Hatta Kabupaten Kubu Raya”. Pontianak: Universitas Tanjungpura.

Rizkia, Selvia Rahma. (2017). “Analisis Perbandingan Kehilangan Prategang Akibat Metode Stressing Satu Arah dan Dua Arah pada Jembatan Beton Prategang”. Lampung: Universitas Lampung.

RSNI T 12-2004 Perencanaan Struktur Beton untuk Jembatan

Soegiarso, R. (2018). "Bahan Kuliah Struktur Jembatan, Fakultas Teknik Universitas Tarumanagara, Jakarta”.

Sullivan, S. R. (2013). "Behavior of Transverse Joint in Precast Deck Panel System”, MSc. Thesis. Ohio: College of Engineering and Technology of Ohio University.

Soetoyo. (2017), Bahan Kuliah Konstruksi Beton Pratekan, Fakultas Teknik Gunadarma, Jakarta.

SNI 1725:2016 Pembebanan untuk Jembatan 